\title{
MODAL WORDS OF POSSIBILITY IN THE TRANSLATION FROM RUSSIAN INTO CHINESE: HULL-ORIENTED ANALYSIS
}

\author{
Guzel M. Nurullina ${ }^{1}$ \\ Tao Yuan ${ }^{2}$ \\ Liliya A. Usmanova ${ }^{3}$
}

\begin{abstract}
The article deals with the modal words with the meaning of the possibility in the translation aspect from Russian to Chinese. The attention is focused on the ways of possibility modality expression in the linguistic corps of the languages being studied. The relevance of this work is determined by the fact that it relies on a contrastive description of the linguistic facts of Russian and Chinese languages and is carried out in line with the modern comparative-typological approach to the study of modal words with the meaning of possibility. The article attempts to study the modal words with the meaning of possibility in the framework of Russian-Chinese translation. In order to determine the features of possibility modality translation, the following studies were carried out: 1) the modal words with the possibility value were
\end{abstract}

divided into four types; 2) the search was performed for the correspondence of words and word combinations in a parallel corpus. The scientific work also presented an experimental study, which allows us to conclude that each type of modal words shows different conformity trends in translation: zero correspondence, correspondence and compensation. The quantitative analysis shows that the Russian-Chinese translation of modal words shows the tendency to full correspondence in a greater extent, which is primarily conditioned by similar semantic relations (the reflection of an utterance logical evaluation), expressed by modal words in both studied languages. It should be noted that such factors as the diachronic feature of the Chinese language, stylistics, the acceptance and the non-acceptance of Russian language

\footnotetext{
${ }^{1}$ Kazan Federal University. nurullinagz@mail.ru.

${ }^{2}$ Shaanxi Pedagogical University.

${ }^{3}$ Kazan Federal University.
} 
features influence the translation of modal words with the meaning of possibility from Russian to Chinese.

Keywords: modal words with the meaning of possibility, correspondence, Russian, Chinese, linguistic corpus, translation.

\section{Introduction}

In modern linguistics, the issue of nature and the essence of modality category consideration is one of the most relevant and contradictory ones. Some scientists analyze the modal meaning in terms of diachrony and synchrony, semantics and pragmatics $[1 ; 2]$, other scientists study modality from the standpoint of comparative linguistics and the typology of languages [3]; cognitive linguistics [4], functional linguistics [5] and discourse analysis [6].

It is known that the concept of modality has come to linguistics from logic, in which modality is viewed as a necessary characteristic and the most important property of judgment. Modality determines the content of judgment in terms of the relationship nature between a subject and a sign, the degree of communication between a subject of judgment and its predicate. In traditional logic of judgment, three types of modality are distinguished traditionally: possibility, necessity and reality. The main type of the natural language modality and one of the basic concepts of logic modality is the possibility, which is considered as the category of judgment modality, as a conceptual category with all imaginable nuances of the generalized meaning of possibility, with the moment of possibility transition into reality [7].

It is known that the predicative basis, which is the condition for the existence of the message itself, implements the possibility modality in a language. Russian and Chinese languages have a rich and a ramified system of the ways expressing the modality of possibility.

In Russian language the words "modal modifiers" [8: 320-330] serve as the way of possibility expression at the lexical level. This includes (modal) verbs (c) мочь, (c) уметь, удаться, умудряться, умудриться, the modal predicates (or adverbs) можно, нельзя, вправе, возможно, невозможно, and verbal-nominal phrases with short adjectives and nouns: иметь 
возможность, быть в силах, быть способным.

The system of modal words of the Chinese language includes: 会, 能够, 可 以, 准, 许, 能, 要, 肯, 敢, 愿意 [9: 68].

Chinese scientists comprehend the speech part of these words in different ways. For example, Liu Shuxiang [10] refers them to adverbs; Li Jingshi [11], Zhu Desi [12] argue that the modal words constitute a group of verbs; Zhen Guanglai [13] proposes to consider the modal words of opportunity as a separate part of Chinese language speech.

\section{Methods}

The present work is devoted to the translation of modal words of opportunity from Russian into Chinese. A lot of representative materials and statistical methods are provided by the linguistic corps [14-17] to study and compare the modal words of the considered languages. The study was based on a parallel corpus of Russian and Chinese languages.

Research is related to the identification of translation features during the transfer of modal words of opportunity from the original (Russian) language to the translated (Chinese) language. Thus, during the translation of the modal words of possibility, one should take into account such features of translation as correspondence, translation error and sentence structure.

In order to study the ways of modality expression with the meaning of possibility in the translation aspect, the following research methods were conducted in Russian and Chinese:

1) the division of modal words of opportunity into four types in order to search for correspondences of words or word combinations in a parallel corpus and to analyze the correspondence of translation from Russian into Chinese;

2) the analysis of translation errors and the study of "original language penetration" phenomenon in translation. It should be noted that the penetration of the original language in China denotes the influence of European languages (the borrowing of elements from grammar and vocabulary) into Chinese.

\section{Results}

The scientific base of this work is a parallel body of Russian and Chinese languages, which includes the scientific texts of humanitarian and social 
orientation. This corps was first established at the Shenyi Teacher Training University under the leadership by Tao Yuan, and at present it is the only corps in China (supported by the grant from the Bureau of the National Fund for Social and Human Sciences of the People's Republic of China). At the first stage of the work, the volume of the corpus was 5,000,000 tokens, the corpus included the parallel texts in Russian and Chinese, as well as a comparable corpus of scientific texts in Chinese [18]. The corps is divided into 4 subcorps, including the texts on politics and international relations, literature, translation studies and linguistics. At present, it also includes the subcorps on management, history, and culturology; thus, the volume of the corps reached 10,000,000 tokens. Metatext and morphological marking was carried out, they planned the work on syntax and semantics.

$$
\text { Using the concordancer }
$$

"Wordsmiths", we got the data that the number of modal word use in the corps makes 2320: мочь, уметь, можно, возможно / невозможно, нельзя, способен / не способен, иметь возможность / не иметь возможность, иметь / не иметь право, получить разрешение, быть в состоянии / не в состоянии, быть в силах / не в силах, etc. We divided these constructions into four types by meaning and performed the quantitative analysis (See Table 1).

Table 1.

\begin{tabular}{|c|c|l|l|c|c|}
\hline $\begin{array}{c}\text { Typ } \\
\mathrm{e}\end{array}$ & $\begin{array}{c}\text { Modal words } \\
\text { of Russian } \\
\text { language }\end{array}$ & $\begin{array}{c}\text { Correspondenc } \\
\mathrm{e}\end{array}$ & $\begin{array}{c}\text { Correspondin } \\
\text { g words or } \\
\text { phrases }\end{array}$ & $\begin{array}{c}\text { Numbe } \\
\mathrm{r}\end{array}$ & $\begin{array}{c}\text { Correspondenc } \\
\text { e in \% }\end{array}$ \\
\hline \multirow{2}{*}{1} & \multirow{2}{*}{ МОчь } & correspondence & $\begin{array}{l}\text { 能, 可能, } \\
\text { 会 }\end{array}$ & 505 & $54.7 \%$ \\
\cline { 3 - 6 } & zero & & 393 & $42.5 \%$ \\
\cline { 3 - 6 } & correspondence & compensation & $\begin{array}{l}\text { 或多或少, } \\
\text { 某种程度上 }\end{array}$ & 26 & $2.8 \%$ \\
\hline
\end{tabular}




\begin{tabular}{|c|c|c|c|c|c|}
\hline & & \multicolumn{2}{|c|}{ Result } & 924 & $100 \%$ \\
\hline & уметь & correspondence & 能, 会 & 31 & $100 \%$ \\
\hline \multirow{5}{*}{2} & \multirow{4}{*}{$\begin{array}{l}\text { можно, } \\
\text { возможно } \\
\text { /невозможно }\end{array}$} & correspondence & $\begin{array}{l}\text { 可以, 可能/ } \\
\text { 不可能 }\end{array}$ & 559 & $68.3 \%$ \\
\hline & & $\begin{array}{l}\text { zero } \\
\text { correspondence }\end{array}$ & & 238 & $29.1 \%$ \\
\hline & & compensation & $\begin{array}{l}\text { 是......的, } \\
\text { 才能 }\end{array}$ & 21 & $2.6 \%$ \\
\hline & & \multicolumn{2}{|c|}{ 合计 } & 818 & $100 \%$ \\
\hline & нельзя & correspondence & $\begin{array}{l}\text { 不能, 不可 } \\
\text { 能, 不应 } \\
\text { 该, 不, 无 } \\
\text { 法 }\end{array}$ & 238 & $100 \%$ \\
\hline \multirow{3}{*}{3} & \multirow{3}{*}{$\begin{array}{l}\text { Способен/ } \\
\text { неспособен, } \\
\text { иметь } \\
\text { возможность } \\
\text { / не иметь } \\
\text { возможность }\end{array}$} & correspondence & $\begin{array}{l}\text { 能, 有...... } \\
\text { 的能力 }\end{array}$ & 38 & $67.9 \%$ \\
\hline & & $\begin{array}{l}\text { zero } \\
\text { correspondence }\end{array}$ & & 18 & $32.1 \%$ \\
\hline & & \multicolumn{2}{|c|}{ Result } & 56 & $100 \%$ \\
\hline \multirow{6}{*}{4} & $\begin{array}{l}\text { иметь / не } \\
\text { иметь право }\end{array}$ & compensation & $\begin{array}{l}\text { 有......的理 } \\
\text { 由, 有....... } \\
\text { 的权力 }\end{array}$ & 56 & $100 \%$ \\
\hline & $\begin{array}{l}\text { получить } \\
\text { разрешение }\end{array}$ & compensation & 可以, 能 & 31 & $100 \%$ \\
\hline & \multirow{4}{*}{$\begin{array}{l}\text { быть в } \\
\text { состоянии/ } \\
\text { не в } \\
\text { состоянии, } \\
\text { быть в силах/ }\end{array}$} & correspondence & 能够, 无法 & 106 & $63.9 \%$ \\
\hline & & $\begin{array}{l}\text { zero } \\
\text { correspondence }\end{array}$ & & 8 & $4.8 \%$ \\
\hline & & compensation & 有能力 & 52 & $31.3 \%$ \\
\hline & & \multicolumn{2}{|c|}{ Total } & 166 & $100 \%$ \\
\hline
\end{tabular}




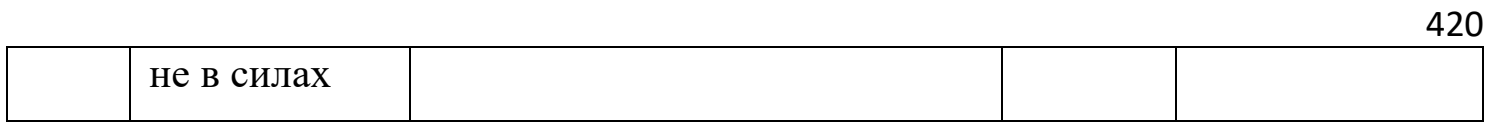

Table 1 shows that the frequency of the modal words слов «иметь / не иметь право», «получить разрешение», «способен/ неспособен», «иметь возможность / не иметь возможность» и «уметь» is less than $60 \%$ in the corps. The percentage norm of the modal words "быть в состоянии/ не в состоянии, быть в силах/ не в силах" and their Chinese equivalents makes more than 50\%; "нельзя" most often corresponds to the Chinese equivalents "不能, 不会, 不应该, 不" (percentage rate - 100\%); the percentage norm of modal words "можно, возможно/невозможно", and their Chinese equivalents makes $68.3 \%$. Modal words "мочь, можно, возможно /невозможно" have the zero correspondence of $42.5 \%$ and $29.1 \%$. The result of the search showed that the zero correspondence of the modal words is closely related to their compatibility. The modal words "можно, возможно /невозможно" when combined with the words "говорить, отнести, составить, обозначать, свести" often display a zero correspondence with their Chinese equivalents. In combination with the words "быть, иметь, вести" the modal word "мочь" also displays a zero correspondence.

Experimental research allows to draw the conclusion that each type of modal words during the translation shows different conformity trends: zero correspondence, correspondence and compensation. The quantitative analysis shows that the tendency towards full correspondence is observed to a greater degree, which is primarily conditioned by similar semantic relations (the reflection of the logical evaluation of an utterance), expressed in modal words, in Russian and Chinese. It should be noted that such factors as the diachronic feature of the Chinese language, stylistics, the acceptance and the non-acceptance of Russian language features influence the translation of modal words with the meaning of the possibility from Russian to Chinese.

\section{Discussion}

Translation correspondence is closely related to the semantic proximity of translated words of the original language and the translated language. The closer their semantics, the more 
often the correspondence tendency. For example, the Russian modal word "м $\mathrm{O}$ ч b " and Chinese "能, 可能" are close in semantics. Xie Kun [19] believed that the words " $\mathrm{M} \mathrm{O}$ ч $\mathrm{b}$ " and '能' express "epistemic modality", "aletic modality" and "deontological modality". The word " м о ч $\mathrm{b} "$ is used in affirmative and negative sentences, corresponds to "能" and "可以" in the Chinese language. The modal words with the meaning of the possibility in Russian and Chinese show an "implicative relation" in semantics [20: 77], and in this regard the tendency to correspondence is manifested in the translation.

\section{Conclusions}

The study in the translation aspect of modal word functioning with the meaning of the possibility in linguistic corpuses made it possible to obtain a multifaceted idea of possibility modality and the ways of its implementation in the systems of Russian and Chinese languages. The analysis of the scientific literature allows us to study and examine in detail the contradictory nature of modality category, which determines the content of judgment in terms of the relationship nature between a subject and a sign, the degree of communication between a subject of judgment and its predicate. The scientific base of this work is a parallel corps of Russian and Chinese languages, which includes scientific texts of humanitarian and social orientation. The conducted experimental research allows to observe different correspondence trends in the RussianChinese translation of modal words (zero correspondence, correspondence and compensation). The quantitative analysis shows the tendency to correspondence in Russian-Chinese translation of modal words. This kind of correspondence is primarily conditioned by similar semantic relationships ("implicative relations"), expressed by modal words in Russian and Chinese.

\section{Acknowledgements}

The work is performed according to the Russian Government Program of Competitive Growth of Kazan Federal University.

\section{References}

Traugott, E. \& Dasher, R. 2002. Regularity in Semantic Change. New 
York: Cambridge University Press.

Papafragou, A. 2000. Modality: Issues in the Semantics-Pragmatics Interface. Amsterdam: Elsevier.

Palmer, F. 2001. Mood and Modality $\left(2^{\text {nd }}\right.$ edition). Cambridge: Cambridge University Press.

Langacker, R. 1991. Foundations of Cognitive Grammar (Vol. 2). Stanford: Stanford University Press.

Givon, T. 1995. Functionalism and Grammar. Amsterdam / Philadelphia: Benjamins.

Hopper, P.J. \& Thompson, S.A. 1984. The discourse basis for lexical categories in universal grammar. Language, 60(4). Pp. 703-752.

B.F. Lomaev. Modality of Possibility in Logic and Language // Young Scientist. - 2014. - №3. - pp. 834-837. — URL https://moluch.ru/archive/62/9466/ (reference date: 02.05.2018).

Zolotova G.A. Communicative grammar of Russian language / G.A. Zolotova,
N.K. Onipenko, M.Yu. Sidorova. Moscow: Institute of Russian language named after V.V. Vinogradov, RAS, 2004. - 544 p.

Peng Lizhen. 2005. Research modality of the modern Chinese language. Diss. for the scientific degree of Doctor of sciences. Fundan University. 2004. №1.

Liu Shuxiang. 1982. Fundamentals of Chinese language grammar. Beijing: "Shanu" publishing house.

Li Jinxi. 1992. New grammar of Chinese language. Beijing: "Shanu" publishing house.

Zhu Desi. 1982. Guide to Chinese language grammar. Beijing: "Shanu" publishing house.

Chen Guanglai. 1980. The study of functional words. Bulletin of Fudan University (collection of linguistics). (1). pp. 40-51.

Alyokhina T.A., Shchuklina T. Yu., MardievaL.A. Teaching Russian composites: normative and derivative aspects (on the material of compound 
adjectives in the Russian language) // Modern Journal of Language Teaching Methods.-2016.-Special Issue. - Pp. 207211

Yusupova Z. F., You Lu, The theory and practice of studying pronouns by chinese students-philologists // Yazyk i kultura Language and culture. - 2017. - Vol., Is.39. - P.75-83.

Kryukova N.I, Zakharova A.N, Dulina G.S, Yusupova Z.F. Didactic features of pedagogical interaction as the basis of university education // Man in India. 2017. - Vol.97, Is.3. - P.29-41.

Erofeeva I.V., Adjective in the linguistic world-image of Russian medieval period (On the material of chronicles)//XLinguae. - 2017. - Vol.10, Is.3. - P.237-245.

Zakharov V. P. \& Tao Y., 2015. The Development and Use of RussianChinese Parallel Corpus. Automatic Documentation and Mathematical Linguistics. Vol. 49 No. 2

Xie Kun. 2014. The study of modal predicates of Russian and Chinese languages from a logical and semantic aspect - "мочь (смочь)" and the Chinese word "neng" in practice. Bulletin of Foreign Languages under the PRC Army. (6): 124-131.

Zhang Huysen. 2001. Comparative analysis of Russian and Chinese languages (part 1). Shanghai: The publishing house "Shanghai Foreign Language Training" 